\title{
Economic Crisis: Theory or Ideological Failure?
}

\author{
Nurul Hilmiyah 1 \\ Bayu Taufiq Possumah² \\ Muhammad Hakimi Mohd. Shafiai ${ }^{3}$

\begin{abstract}
Ph.D Student of Islamic Economic, Institut Islam Hadhari, Universiti Kebangsaan Malaysia Lecturer at School of Social and Economic Development, University Malaysia Terengganu, Malaysia Senior Lecturer at Faculty of Economic and Management, He is also Research Fellow at Institut Islam Hadhari Universiti Kebangsaan Malaysia
\end{abstract}

\section{Doi:10.5901/mjss.2016.v7n2p90}

\section{Abstract}

\begin{abstract}
Today global economic system practiced is commonly derived from Western thought and civilization. A lot of research has shown that this modern economic system unsuccessful in achieving economic goals, moreover this system produce a negative effect as causes of various economic problems, such as crisis, inequality distribution, poverty, and war in various countries. The matter then leads us to find what exactly source of the problem is. By using qualitative analysis with content analysis technique, this paper attempt to identify two points related to economic theory and problem. Firstly, does the economic problem linked to the economic theories itself or by human behavior? Secondly, does economic system, theory or ideological failure? This study argues that economic theories closely related and unseparated to ideology or religion matter which has develop the human perspective on how to solve the economic problem. This paper designed also to realign the contemporary economic system and their economic theory compared to the Islamic economic system based on Tawhid. This study found that the lack of fundamental ethical norms, political economy, morality and the pursuit of unbridled self-interest, is the main problematic issues and cause of the economic problems as the findings. The implication is that the economic system should adopt Tawhidic system as an answer and solution of human economic phenomenon.
\end{abstract}

Keywords: Economic system, Paradigm, Ideology, Ethics

\section{Introduction}

The phenomenon of economic failure cannot be avoided by all countries. This indicates an error has occurred in the global economic system. Modern thinkers make humans seem as tool and cannot affect the system. The system cannot serve itself and the human then become part of the system. In modernism literary, in Shaikh (2009), Marcuse described this phenomenon as 'One Man Dimension'. If the system stable and provides a benefit, the system no need to be customized, as created and made to operate. However, if the system does not deliver the expected results, they can and should be modified to provide the expected result (Shaikh, 2009).

Currently, various worlds profess on free market system. Money flow in and out freely from one country to another, with the various financial regulations. When all countries linked each other in the global economy, all countries placed in risk of crisis. Crises occurs with a various economic downturn, social and political, the outbreak of the revolutions among the various types of state, whether in the form of colonization or warfare, with the goal of opening markets and exploit other nations (Eisenbeis, 2010). As Gaudenz et. al, said "That the next step consists of a new perception of the economic turmoil, this time not anymore as a crisis, but rather as an opportunity to modify the fundamentals of the initial worldview" (Gaudenz et al. 2011). He also emphasized that the economic issue not only about the financial crisis but even how we see worldly life and also the opportunities of the transformation what this economic system brings. The opportunities to re-think the Western worldview with some core assumptions (Gaudenz et al. 2011).

The main topics of economic theory such profit-maximization as the derivatives of the value of utility maximization, or the pursuit of self-interest, has become longstanding controversy. These attributes are believed bring into being a good society based on one group critics, because they things the self-interest and profit-maximization is only possible way to achieve a prosperous economy that make people to leave from the poverty. They believes in, only the power of the invisible hand which can controls self-interest in a suit place, so can achieves the best outcome for society (Gaudenz et al, 2011). Another group contradict with this perception, signalize that the principle of invisible hand is only about the 
metaphysical construct and that the cause of economic problems such as extreme wealth disparity, ecological problems and the economic crisis, all those phenomenon show that the invisible hand does not work properly. Thus, through the content analysis approach this paper try to review the basic postulate of the principle of modern economic system with its various paradigms in explaining Western economic system and the various factors that have brought to the cause of the economic crisis, know definitely impress and critics to the failure of the capitalist economic system, in order to achieve an economic revival in the short term and to create prosperity as development goals in long term.

\section{Economic System in Western Discourse}

At the beginning of Europe modern period, Western economic paradigm brought by mercantilism which practiced by European aristocrats in the political unity paradigm and national strength framework (Cranny, 1998). At the 19th century, economic thought generated by Count Saint-Simon, Charles Fourier, Robert Owen, and Karl Marx with their socialist paradigm. Socialism is a political-economic system which government ownership and controlled the tools of production. Sometimes, the system is called a "socialist" and as some economist called the economy with "centralized command system". Centralized system mean that the system design to control the various modes of production by government, on emphasizing the control of state and its role, not private property ownership industry (Hayek, 1994). Socialist spread malice and hatred to the capitalists. Following their view, that human development begins from the development of tribal, feudal, bourgeois (capitalist), then up to the last level that requires the breakdown of the socialist, and also spread envy culture between classes. Socialists monitor the local conditions by the parties, as a springboard to dominate the government (Hayek, 1994). When successful, then the law and democracy should be abandoned, then socialist or communist must be the only politicians adopted.

Another western system is capitalism paradigm, according to Aydin (2013) the capitalism paradigm is an ideology that makes money (capital) the central purpose of life for all individuals. Also Marx Lederer (1958) stated "Money is the estranged essence of man's work and man's existence, and this alien essence dominate him, and he worships it" In this context, the ultimate goal is accumulation or gain money wealth. The conversation of money into the god of the world is capitalism ideology by Marxist. It is a secular ideology, which promised by many religions, this ideology will create a "technological paradise" in this life, not in the next life. Then capitalism becomes a secular religion in this context, with their "laissez-faire", thus their goal is 'freedom of market from any government intervention'. It relies on the individuals assumption followed by their self-interest. According to Adam Smith, the self-interest is an act and part of human nature. According to Aydin (2013) from Smith's understanding of human nature, that "it is not from the benevolence of the butcher, the brewer, or the baker, that we expect our dinner, but from their regard to their own interest" (Smith 1976, pp.26-27). (Smith 1976, p.26-27) In his 'Wealth of Nations', Smith argues that in order to enrich their wealth, every man should be "free to pursue his own interest his own way, and to bring both his industry and capital into competition with those of others" (Smith 1990, p.687).

Capitalist market economy is a system that is concerned with the maximum profit. It was done by producing goods which give more profitable that benefit, as well as creating the procurement market through monopoly by abusing the price value of goods. Refer to Osterfeld (1991) as a system of human relation economics often viewed as a system on how to gain from another person's loss. Since both the market and the state are tools which are used by the wealthy elite to protect and enhance their own privileged positions by oppressing and exploiting the poorer, working class, there is no need to distinguish between them.

Accumulation of capital by the merchants and rich farmers, like Baran (1999) noted that, this cause of the state support the competition in the form of trading capital by European market basis. Thus, Baran argue that the capitalist development as the development in one region at the expense of other regions. Baran laid the foundations of capitalist exploitation is explaining how this colonial expansion brought to the dependence number of state extended by a number of neo-Marxist theorist (Sen, 1987). The critiques of the oppressive capitalist followed by the birth of neo-liberalism system and the free market system as a reaction to destroyed the market system. Neoliberal influenced by neoclassical economic theory that refers to a political-economic philosophy, this include the redefinition and an extension of classical to reduce the power of local government in the economy, in order lead to the creation of the deviation and the high cost economy, towards to the corruption.

The multilateral political pressure is a part body of neo-liberalism, through WTO and the World Bank (Kotz, 2002), thus reducing the power of the state until the minimum point, such the reduction of the rights labor policies (minimum wage) (Harriss-White, 2005). Thus, trade fair and other social justice movements became an obstacle of neoliberal that supposed to be the most priority on international relationship of economic. Another popular picture of ideological steamroller of neoliberal globalization is IMF, which the relations of fund proven to be a resilient force with the 
partisanship of domestic politics in developing countries'. Eleches (2013) and Pastor (1987) also declared that "since IMF programs also have important domestic distributive implications, it is not surprising that the negotiations surrounding the initiation of their programs is inextricably linked to partisan competition in developing countries" (Caraway et al 2012, Eleches 2009, Stone 2002).

The neoliberal often makes the business privatization as a policy and deregulation concern (e.g. elimination of, or cutbacks in social welfare programs; and reduction of taxes on businesses and the investing class). The macroeconomic instability under neoliberal model created to counter cyclical spending and taxation policies, Kotz clearly stated in this context that

"by reducing effectiveness of 'automatic stabilizers' through shrinking social welfare programs, and by loosening public regulation of the financial sector. The term 'automatic stabilizers' refers to government programs which pump increasing funds into the economy when economic growth slows or stops, thus limiting the severity of economic downturns. Examples include unemployment compensation and welfare payments" (Kotz, 2002).

The economic activity of neoliberal is the efforts of industry-owned and government-run (Harriss-White, 2005). Neoliberal based on inventories to demand principle. According to them the low inflation and high unemployment better than the high inflation with the low unemployment in the economic condition (Krugman, 2009). The principle of profit and loss applied in all public services. They thought that such subsidy will be the inefficiency things (Cox, 2012), because this system is not concerned with the quality of public safety. In this case the establishment policies and public funding of the government are cutting production as subsidies, in order reducing the facilities for public welfare.

Basically economic thought was produced over hundreds years but still incomplete and continues to evolve as the development of society that increasingly complex. Then born the various kinds of economic theory (as described above) brought by the Western economic system in trying to solve the economic problems.

\section{Does Economic Problem Linked to Economic Ideology?}

Currently, not a few of economist see that the crisis is an opportunity to re-think fundamental assumptions and theory of the Western economic system. On the basis pessimism and optimism, Gaudenz et al. (2011) argues that the good starting point in the course of reform this issue starts from some critical fixes basic assumptions about the world economic system should be applied. But until now the western economic system still gives the impression of a significant negative for all mankind in various countries. Between the impressions caused by the failure of the economic system are:

\subsection{Crisis}

The phenomena of financial crisis cannot be separated from the nature of capitalism that is rooted in the mainstream economic system that brought the U.S. and the various countries of the world. Both in theory and practice capitalism associated with crises which may pauperise various fractions of society. The crisis of fuel and food, and continued with the financial crisis that lead us to dealing not only the collapse of financial system, but also the collapse of a worldview' as well. In Eisenbeis (2010) noted that Fergusson et al. (2010), has been analyze the crisis starting under the laconic formulation of George Soros analysis and three years from the global economic meltdown, the mainstream economist then explain that meltdown is a result of a delayed diagnosis of insolvency and the failure short-term economic policies, such as sub-prime lending or the misuse of innovative financial market mechanisms such as securitization, CEOs, etc. In the case of U.S, started in 1980, a crisis has occurred, among other crises financial international in 1982, Insolvent Continental Illinois in 1984, and the failure of Long Term Capital Management in 1998, in every crisis financial authority that channel funds to help the economy bounce back (Soros, 2008).

The root causes of economic crisis were the requirement of housing installment payment. They provide a fixed interest rate for three years. The problem is, many financial institutions installment of the U.S housing distribute it to the people who do not deserve funding, thus causing buildup installment payment (the subprime mortgage) and the impression of a domino collapse of major institutions America's financial (New York Times, 2008). It also affects the liquidity of the financial, either financial institutions or outside of the United States.

This is financial crowded going to be the bubble or as Krugman (2009), calls 'the shadow banking system' caused by the unregulated nature of system. Krugman (2009) then argues that capitalism has a need for financial bubbles because when the housing bubble burst, the lack of a replacement bubble led to widespread crisis. In addition lannauzi and Berardi (2010) in their study showed the housing price inflation from the middle of 2003 up to the beginning of 2006, 
that the housing price inflation increase sharply and the subsequent decline. From their study, according to Taylor (2009) it can take the observation that "delinquency rates and foreclosure rates were inversely related to housing price inflation during the same period" (Taylor, 2009, p. 11). According to their study figure 1 show that "housing price inflation and subprime ARM delinquencies and foreclosures the boom-bust in housing starts compared with the counterfactual" (Iannauzi and Berardi, 2010). It will be the one evidence of the impact from the economic crisis.
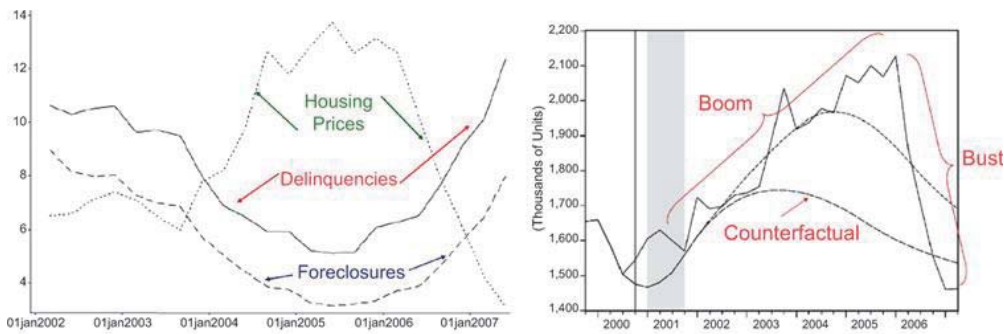

Figure 1: housing price inflation and subprime ARM delinquencies and foreclosures ${ }^{1}$

Certainly, the self-interest also plays a strong role as an ideology along with the crisis. Accordingly, Epstein and Hagenbarth (2012) said that it seems to be a consensus forming of economists: "they did not predict the solution of the crisis is to promote austerity, which is not only about the inequitable, but also ineffective the underlying problems that caused the crisis in the first place. The economy's profound solving not only about a lack of strong financial regulation and austerity would to be a winning formula for solving this crisis, but also (they argue) that "ideology plus conflicts of interest among academic financial economists play a joint, powerful, yet hard to disentangle role in this widespread lunge toward crisis and austerity".

Additionally, Eleches (2013) expressed that The IMF programs of Latin American and East European also initiated during the global financial crisis into historical perspective by comparing to the patterns of IMF engagements in the quarter-century before the current crisis. He emphasized, it have "two fold claim are ideology and regional context matter and that ideology has generally mattered more in the post-Lehman crisis than in previous crises". Thus, Eleches also declared that in Latin America the effects were stronger than the last three decades, while in Eastern Europe it matched with the partisan intensity of the first post-communist transition decade. Specifically, in Eastern Europe the divergent partisan responses not only external but also domestic economic challenges were trigger the recent crisis that resulted in differences partisan which is increasing the response to deteriorating economic circumstances Eleches (2013).

A number of emerging views of the causes of the global financial crisis, such Stiglitz (2009) noted that crisis is 'failure system' which began at the turn of Paul Volcker, Volcker saw that the financial markets need more regulation. Other causes visible from around Wall Street policies that provide coverage over the U.S. banks in speculation, the issue of derivative financial products, and budget policy at the George W. Bush period (Stiglitz, 2009). Eichengreen (2008) and Boltvinik (2013) also look at the roots of the crisis caused by the greed of market participants (greed and corruption on Wall Street) in the free trade system. Dissaving U.S. economic policy also makes a recession in 2001, which then makes installment be so easy to obtain in large quantities. It shows the weakness of the capitalist economic system that is based solely on speculation forecasting business profits, regardless of the reality that the world economy is underway.

Hence, when the transformational pressure on the system is growing and a high plenty number of people are affected, the profound paradigmatic discussion become an opportunity to gain relevance area and may be as a managerial puzzle of economists to find the best solution using the existing economic mechanisms, to introduce a new worldview system.

\subsection{Poverty}

The concept of poverty according to Harriss-White (2005) and Laderchi et al, (2003) having many dimensions: monetary (income poverty), human development poverty, social exclusion and poor peoples' own understandings developed through participatory interactions. As Harriss-White (2005) noted that "the choice of a poverty line of $\$ 1 /$ day as a state to

1 Taylor (2009) 
be eradicated is well recognised to be an arbitrary goal" (Harriss-White, 2005). Harriss also stated that the Commission for Africa (at 2005) issued a strong statement that the solution of Africans poverty by the business expansion. In this context, he mentioned that the major 'development partner' of the poor is capitalism. Again, according to Harriss-White (2005), he emphasized that 'we have not yet come full intellectual circle because, in being stylised as 'business' and commonly also as 'markets' and 'economic growth', capitalism is robbed of its logic, its institutional framework and its dynamic" (Harriss-White, 2005).

The falsity of the World Bank about the world poverty by Sanjay Reddy and Thomas Pogge (2010) as quoted in Boltvinik (2013) shown that the long term index by World Bank depends highly on the international poverty line (IPL) used to measure the poverty. If the World Bank using official IPL of $\$ 1.25$ (of purchasing power parities, PPP) per person per day, the number of poverty decreased by $27 \%$ between 1981 and 2005; but if using a $\$ 2.00$ IPL, it increases by $1 \%$, and if using IPL of $\$ 2.5$ it increases by 13. There are three different diagnoses: so they stated that "the lower the IPL, the more optimistic and more favourable the outcome for neoliberal capitalism". Reddy and Pogge (2010) also emphasized that "the World Bank's official IPLs have been falling in real terms, even though the institution has tried to give the opposite impression". They stated that the truth of the original IPL (\$1.00) (in terms of 2009 purchasing power), while between 1990 and 1997, when the purchasing power was \$1.08, the IPL was \$1.99 dollars; and between 2000-2008 was $\$ 1.60$ dollars and purchasing power was $\$ 1.25$ which is being used until now and equivalent to $\$ 1.37$ dollars. The World Bank gives indentation the falling of poverty by lowering the real IPL. Thus, in their sum, "thereby adding falsehood to the open and shameless cynicism that is implied in offering, to nearly half of the world's population, a perspective of barely surviving like an animal, which is the only attainable standard of living on \$1.25 per day". While Reddy and Pogge measure the IPL is not just based on the need of food, but also for other needs. According to Boltvinik (2013) also stated that "the World Bank takes food as the unique human need, leaving all other needs fully unmet, thereby revealing a conception of human beings as animals".

Additionally, the capitalist mode of production is different to the social consequences of the product or commodities itself which is and resulting in socially harmful ${ }^{2}$. Society at macro level may be destructed by harmful products which are dangerous to humans and social life. At the micro level also the product may be recycled and modified to create more jobs. But, in reality, a lot of waste cannot be made of recyclable materials, either by price or because damage of the quality. This then reinforces the need for capitalist societies to deal with commodities which damage people and create poverty", although they think that has been created the wealth.

\subsection{Unfair distribution}

At 1970 was a period when world oil prices have increased, which impact on economic growth and income distribution. Inequality of income distribution increased between 1969-1970 and 1976 (Booth, 1981). World Development Bank (2005) showed the empirical study that there are inequality income and wealth in the second half of the 20th century. According to Kuznets (1955) "inequality income distribution caused by the different productivity possessed by every individual which one individual or group has a higher productivity compared another individual or groups". Alderman and Morris (1974) showed that an increase in GNP per capita in line with the worsening of income distribution in the early stages of development, but only the countries that have high national income has a positive relationship between GNP per capita to the level of equality in income distribution. Chapra (1993) also said that the inequality income distribution gives more weight to certain classes of society to influence the allocation of resources for the desired use.

Additionally, according to Adelman, Morris (1973) and Arsyad (1997) inequality source of income is due; inflation, implementation of import substitution industrial policy resulted in price increases to protect the efforts of the capitalists. The worsening of the exchange rate (terms of trade) for developing countries in free trade, as a result of inflexibility request countries to export goods in developing countries. It is also about inequality development among regions, low social mobility, destruction of craft industries, such as construction of buildings, household industry, etc., caused the small business community not growing, but large industry that can thrive (Morris, 1973 and Arsyad, 1997). Thus, causing them to lose income and create unemployment.

Naturally, capitalist system has created rapid economic growth, that only enjoyed by the developed countries that are rich in capital, although this also enjoyed by some developing countries, but few benefits to solve the problems of poverty and fair income distribution. The emergence of slums in the middle big city, while in other areas we found the luxury housing, it is a clear evidence of inequality. Distinction in people's lifestyle is another proof of the inequality and injustice. Unfair distribution of income is something that had to be sacrificed in order to stimulate rapid economic growth.

${ }^{2}$ See Carrick-Hagenbarth, J, and G.A. Epstein, (2012) 


\subsection{War}

Physical warfare just occurs in early of the capitalist, as a form of rebellion from the mercantilist. Early capitalism (15001750) was marked by the accumulation of mercantilist policy of gold and silver, it is also marked by the emergence of empire in Western Europe such as Spanish, Portuguese, Dutch, French and England. Imperium between the greedy of capitalist makes them fight each other to colonize other nations that may compete for treasure. The gravity of the economic, social and political or the breakage of various types of revolutions occur between countries, whether in the form of colonization or war, forcing the country to open up the market with aim to exploit other nations and dominate the weak. A capitalist country and the Socialist state do a competition, agitation, tension and suspicion that led to the conflict, it causes the cold war. Cold war is a form of warfare that do not use direct force of arms, but using methods, tools, and strength of ideology, political economy, social, cultural and other tools, to achieve the national goals whether it capitalist or socialist (Murtamadji, 2010).

One of the real evidence is the development of nuclear weapons, which can killed 12 times the world's populations it is a destructive force that impact of long time enough, until one generation to the next. As expressed by Jacob T (1997) "the impact of nuclear war is so vast and cruel. The worst is impact is human extinction, destruction of the environment, and impaired global biosphere and stratosphere. The impact of mass death often occurs due to heat and radiation explosion, followed by fire and damage the ancillary system (electricity, communication, transportation, pollution of water sources and food). The victims who not die will be exposed to radiation sickness, burns, bleeding, psychological shock, leukemia, and genetic effects, which reduce the variation gene disorders in the next generation. Nuclear war between America and the Soviet Union currently predicted casualties of 200 million dead, 60 million wounded, 30 million more will be affected by radiation sickness, 20 million will suffer trauma and burns.

Another war created Capitalists against another country is taking and control of valuable resources such as oil, gold, silver and other mining. It was created through the global financial system in the game world of interest rates. Speculation interest makes the rate up and down lead to a global crisis, its effect to other countries. Another effect is that inflation, the collapse of the national currency exchange rate, unemployment, and poverty. This downfall, they utilized to help their economies (with the 'intention' of profit). This assistance is usually in the form of an IMF loan funds or the form of cooperation such as oil processing industry mining. Levels of interest specified that must be paid for their debt. Because of the great interest rates being incompatible with National income is positive, so most countries can only pay interest on half the entire period of the agreements. That's why, these countries not able to pay off the debt on the entire period specified. They can only renew the old debt agreement with a new timeline. This phenomenon has resulted in growing dependence on the National State authorities, which can be referred the hidden colonization.

It is clear that the explanation above as the other problems and failures brought by the economic modern system. It's just lethal and contempt for humanity, without giving the slightest spark of life in the future. Where the peace, social care and well-being that should be realized by this system? Does it give real solution or just economic welfare mere ideology?

\section{Economic in Tawhidic Worldview}

As Choudhury (2011) stated that "the link between Tawhid, Islam, and economy, is the central or core concept which permeates all aspects of Islamic economic epistemology is Tawhid or the unity of God". Fadl and Smith also argue that the epistemology of Islamic economic, "there is a higher authority than the senses and human reason which provides the stable "vertical axis" (the transcendent) to which the "horizontal axis" (efforts of humans)" can refer to as a point of reference Fadl (1991). This is what is implied when a person declares the Shahadah or declaration of faith in Islam, i.e., one's acceptance of God's authority over one's own. This Tawhidi Paradigm of economic sees human reason aided or rather guided, by revelation as quoted from Possumah (2014). It also implies that economic activities are part of worship, and worship it-self as a realization of Tawhid, therefore the economic activity of a Muslim should be based and relies on Tawhid, as well as all human activities in the political, social and culture.

Choudhury (2011) also claims that Islamic economics relies on different epistemological paradigm which is significantly different from the western secular paradigm (Aydin, 2013). Choudhury (2011) asserts that the prevailing Islamic socio-scientists" are distance from "any substantive reference to the Qur'anic worldview, it's epistemology of Oneness of the Divine laws (Tawhid), the causal understanding of unification of knowledge in world-systems. The Tawhidi paradigm in this context provides the unity between the level of ontological and epistemological without any contradiction between genuine scientific and religious truth (Choudhury 2007b).

In the same manner Asutay (2007) refer to the characteristic value of Islamic economic, that spiritual, and social 
needs (material needs) of human beings. In Islamic economics human well-being is different with hedonic viewpoint; it is assigned from a spiritual, moral, and social perspective (Asutay, 2007). He also emphasized "generally, the Islamic economics is for free market, which provide certain filters to avoid the madness and unfairness of the market". Thus, the determination of the question "what to produce" is based on the conception of human nature and needs comprehensively, not by the self-interest concept.

The particular of Islamic worldview sourced from Qur'an and Hadist which are differences from the materialist worldview (capitalist paradigm), this is become a distinctive features of Islamic economics come from. Therefore Aydin (2013) expressed, "it is important to highlight multi-dimensional well-being goals and morally market mechanism ${ }^{3}$. It should be the best decision when we decide economic activity such as in producing something is to produce goods and services which help people to achieve excellence spiritual, intellectual, moral, and social, produce goods and services for needy people. Produce with efficient and fair market mechanism through an allocation and distribution of scarce resources that is in conformity with Islamic teachings without unduly curbing individual freedom or creating continued macroeconomic and ecological imbalances" (Chapra 1996, as quoted in Aydin 2013).

Therefore, Tawhidic worldview should be the basis for an economic system to deal with the phenomenon of economic failure that caused the crisis, poverty, unfair distribution and warfare. In the case of a crisis for instance, Tawhid can oversee and control the stability of the economic system. As previously explained that poverty is the result of unfair distribution, it can be removed with equality and fraternity. These both elements are the dimension of Tawhid. As for the war only a sense of hatred, greed and envy can take away a peace. It would be nice if we lived in harmony in the balance of life, without negative competition, self-interest and individualism. All of these elements are the basic principle of Tawhid in guiding human life, Muslims and non-Muslims.

Based on the previous mentioned above, it is clearly such this paper declare that to avoid and find a solution to current economic problems, it is time for us not only for Muslim but also for all human beings, to apply the Tawhid based economic system, it should be the kaffah (complete) system, dimensional world and the hereafter. This paradigm has contributed to the harmony and balance of life. Thus, this paper argue that the Tawhidic paradigm do not cause any conflict and contrary to the teachings of other religions. Because, we all believe that all religions have always taught goodness and badness in the lives for each peoples. This needs to be applied to achieve peace, justice and wellbeing for all mankind.

\section{Conclusion}

The West economic system has created a serious problem; it is shown that the system has a lot of questions for the world economy. It can be concluded that the capitalist market economy does not work exactly as economic engines. Developed capitalist system against human value, this is a result of knowledge base and underlying paradigm that reject a number of ideological foundation. Capitalist have strengths and weaknesses; whether socialism or neo-liberalism, it must be evaluated properly in order to develop an economic system that is able to serve the aspirations of humanity. Therefore, the capitalist expand its influence throughout the world, must be questioned, whether to create the well-being of civil society?

This study has identified the lack of fundamental ethical norms, morality and the pursuit of unbridled self-interest, is the main problematic issues in capitalism. This study argues that the global financial crisis, poverty, income inequality and war becomes a negative factor to rethink the basics of system that rooted from their ideologies, because this effect does not lead to solving the economic problems, even increasing the problem of the world economy itself.

It was found that political economy, self-interest, moral and ethics are the cause of the global crisis along the time. Capitalist market system and the nature of the basic paradigm of individualism into the system lead to the poverty and income inequality. Unsuccessful economic systems are a result of weaknesses and disadvantages of each economic system, the weaknesses and deficiencies greater than its advantages. It is thus required new thinking about sustainable economic system through the Islamic economic system.

This system brings the teachings of 'Islamic economic wellbeing' which is in the middle between Capitalism and Socialism. In Islam, Tawhid and ethics as the basis of economic behavior while in the 'Welfare State' is not so, because ethics in 'Welfare State' is secular, it's not directed to the "vertical integration" between the material and spiritual aspirations of creating prosperity for all human beings, regardless of tribe, race and religion. It becomes a must to do to

\footnotetext{
3 Islamic economics foresees an economic system based on the Islamic worldview with ultimate goals to realize spiritual, moral, intellectual, social, and material well-beings of individuals in this life and the hereafter through allocation and distribution of scarce resources in a morally guided market system
} 
create prosperity and wellbeing for all mankind through "Tawhidic Economic" as a modern system.

\section{Acknowledgement}

This research is supported by the Exploratory Research Grant Scheme (ERGS), Grant No: ERGS/1/2013/SS07/UKM/02/ 3.

\section{References}

Adelman dan C.T. Morris. (1973). Economic Growth and Social Equity in Developing Courtier. Standord, California: Stanford Union Press.

Arsyad, Lincolin. (1997). Ekonomi Pembangunan. (3rd ed.). Yogyakarta: STIE YKPN.

Asutay, M. (2007). A Political Economy Approach to Islamic Economics: Systemic Understanding for an Alternative Economic System. Kyoto Bulletin of Islamic Area Studies, Vol. 1, No. 2, pp. 3-18.

Aydin, N. (2013). Redefining Islamic Economics as a New Economic Paradigm. Islamic Economic Studies, Vol. 21, No. 1, 1-34.

Baran, Paul A., and Paul M. Sweezy. (1996). Monopoly Capital: An Essay on the American Economic and Social Order. New York: Monthly Review Press.

Boltvinik, Julio. (2013). Capitalism and Poverty. Automation signals the final stage of capitalism basic income for a peaceful transition to post-capitalism. Mexico.

Booth, A. and Sundrum, R. M. (1981). Income Distribution. in The Indonesian Economy During the Soeharto Era. (A. Booth and P. McCawley ed.). (pp. 181-217). Kuala Lumpur: Oxford University Press.

Caraway, Teri, Stephanie Rickard, and Mark Anner. (2012). International Negotiations and Domestic Politics: The case of IMF labour market conditionality." International Organization, 66(1), 27-61.

Carrick-Hagenbarth, J. and Epstein, G. A. (2012). Dangerous Interconnectedness: Economists' Conflicts of Interest, Ideology and Financial Crisis. Cambridge Journal of Economics, 36, 43-63.

Chapra, M. Umer. (1993). Islamic and Economic Development. Islamabad: Islamic Research Institute Press.

Chapra, M. Umer. (1996). What is Islamic Economics. Jeddah: IRTI.

Choudhury, Masudul Alam. (2007b). Islamic Economics and Finance: Where Do They Stand?. Proceedings of 6th International Conference on Islamic Economics and Finance, Advances in Islamic Economics and Finance, Jeddah: IRTI.

Choudhury, Masudul Alam. (2011). Islamic Economics and Finance: An Epistemological Inquiry. Emerald Group Publishing.

Cox, Michael. (2012). Power Shifts, Economic Change and the Decline of the West?. London School of Economics, Houghton Street. London, WC1 2AE, UK. Sage pub. co.uk/ journalsPermissions.nav (accessed 17 June 2014).

Cranny, Michael. (1998). Crossroads: A Meeting of Nations. (p. 237). Scarborough, Canada: Prentice Hall Ginn Canada.

Eichengreen, Barry. (2008). Anatomy of Financial Crisis. http://www.voxeu.org/index. php?q=node/ 1684/ (accessed 23 September 2014).

Eisenbeis, Robert A. (2010). The Financial Crisis: Miss-Diagnosis and Reactionary Responses. Atlantic economic journal, Vol. 38, No. 3, 283-295.

Ertuna, Ibrahim Ozer. (2008). Wealth, Welfare and the Global Free Market. Istanbul, Turkey: Okan University.

Fadl, Mona Abu. (1991). Beyond Cultural Parodies and Parodizing Cultures: Shaping a Discourse. American Journal of Islamic Social Science Vol. 8, No.1.

Fergusson, Niall, Bill Bradley, Robin Wells, Paul Krugman, and George Soros. (2009). The Crisis and How to Deal with It. Excerpts from a symposium on the economic crisis presented by The New York Review of Books and PEN World Voices. Metropolitan Museum of Art, 30 April 2009.

Gaudenz, A., Zdenka, S. and Aliaksandr, M. (2011). The Ideational Background of the Global Economic Crisis.

Harriss-White, Barbara. (2005). Poverty and Capitalism. QEH Working Paper Series - QEHWPS134. University, Mansfield Road, Oxford OX1 3TB, UK.

Hayek, F. A. (1994). The Road to Serfdom. (50th anniversary ed.). Chicago: University of Chicago Press.

lannuzi, Elio and Berardi, M. (2010). Global Financial Crisis: Causes and Perspectives. EuroMed Journal of Business, Vol. 5, No. 3, 279297. Emerald Group Publishing.

Kotz, David M. (2002). Globalization and Neoliberalism. Paper in Rethinking Marxism, Vol. 12, No. 2. United State of America: University of Massachusetts.

Krugman, Paul. (2009). The Return of Depression Economics and the Crisis of 2008. New York, Norton.

Kuznets, S. (1955). Economic Growth and Income Inequality. American Economic Review, Vol. 45, No.1, 1-28.

Laderchi, K.R., Saith, R. and Stewart, F. (2003). Does It Matter That We Don't Agree on The Definition of Poverty? A Comparison of Four Approaches. Working Paper 107 (QEHWP107), Oxford: Queen Elizabeth House.

Lebowitz, M. (2004). 'Paul Sweezy' Monthly Review, Vol. 56, No. 5.

Marx, K., and Lederer, H. (1958). On the Jewish Question. Cincinnati; Ohio: Hebrew Union College-Jewish Institute of Religion.

Murtamadji. (2010). Gagalnya Perang Antara Amerika dan Unisoviet (P.D II) Di era Perang Dingin Sekalipun Kedua Negara Adidaya Saling Bersaing Persenjataan dan Terlibat dalam Berbagai Konflik Regional di Belahan Bumi. Working Paper, Indonesia.

Osterfeld, David. (1991). Marxism, Capitalism and Mercantilism. The Review of Austrian Economics, Vol. 5, No. 1, 107-114. 
Pastor, Manuel. (1987). The International Monetary Fund and Latin America. London: Westview Press.

Pop-Eleches, Grigore. (2009). From Economic Crisis To Reform: IMF Programs in Latin America and Eastern Europe. Princeton University Press.

Pop-Eleches, Grigore. (2013). Between Economic Necessity and Ideology: IMF Programs Before and During the Global Financial Crisis. Princeton University Press.

Possumah, Bayu. Taufiq. (2014). Islamic Economic: An Epistemological Enquiry. Malaysia: Institut Islam Hadhari. Universiti Kebangsaan Malaysia.

Reddy, Sanjay and Thomas Pogge. (2010). How not to Count the Poor, in Anand, S., P.

Sen, Amartya. (1987). On Ethics and Economics. Oxford: Basil Blackwell.

Shaikh, Salman. (2009). A Comparative Study of the Major Economic Systems in the Aftermath of The Great Recession. MPRA Paper, no. 19588.

Smith, Adam. (1776). [(1937)]. The Wealth of Nations. (Edwin Cannan, ed.). New York: Modern Library.

Smith, Adam. (1990). An Inquiry into the nature and causes of the wealth of nations. Chicago; London: Encyclopedia Britannica.

Stiglitz, Joseph. (2009). Capitalist Fools. http://www.vanityfair.com/magazine/2009/01/stiglitz200901 (accessed 17 June 2014).

Stone, Randall. (2002). Lending Credibility: The International Monetary Fund and The Post Communist Transition. Princeton University Press.

Taylor, J.B. (2009). The Financial Crisis and The Policy Responses: An Empirical Analysis of What Went Wrong. Rock Centre for Corporate Governance Working Paper, 30, 1-30, Stanford University, Stanford.

T. Jacob. (1997). Manusia Ilmu dan Teknologi. Yogyakarta: Tiara Wacana.

The New York Time. (2008). The Financial Crisis: An Interview with George Soros. Review of Books.

World Bank. (2005). World Development Report 2006: Equity and Development. World Bank, Washington DC. World Income Inequality Database V 2.0b May 2007 (http://www.wider.unu.edu/wiid/wiid.htm) (accessed 5 May 2014). 